\title{
PENGARUH MISI, KURIKULUM, DAN KEPEMIMPINAN DI PERGURUAN TINGGI TERHADAP PERILAKU ANTI-RADIKALISME MAHASISWA
}

\section{THE IMPACT OF UNIVERSITY'S MISSION, CURRICULUM, AND LEADERSHIP TOWARD STUDENTS' VIEW OF ANTI-RADICALISM}

\author{
Saifuddin Chalim \\ Universitas Islam Negeri Sunan Ampel Surabaya \\ Jalan Achmad Yani No. 117 Jemursari, Wonocolo, Surabaya \\ E-mail: asep.chalim@gmail.com
}

Naskah diterima tanggal: 10-1-2018, disetujui tanggal: 19-4-2018

\begin{abstract}
The spread-out of radicalism and terrorism needs to be overcome in the very early stage at home, school, university, and community. For that, education institutions should build anti-radicalism attitude for its students through an integrated values of character building. This study aims to analyze the impact of university's mission, curriculum, and leadership towards student's attitude of anti-radicalism. The study is undertaken with a quantitative approach by using a multiple regression analysis, in universities implementing ahlusunnah wal jama'ah principles, nationalism, and insight of nationality. The study found that factors such as leadership, curriculum, and mission significantly have positive impact and big contribution toward student's anti-radicalism attitude .
\end{abstract}

Keywords: mission of university, curriculum, leadership, radicalism

\begin{abstract}
Abstrak: Berkembangnya paham radikalisme dan terorisme perlu dicegah sejak dini di lingkungan keluarga, sekolah/perguruan tinggi, dan lingkungan masyarakat. Menyikapi hal ini, lembaga pendidikan perlu membangun sikap anti-radikalisme para peserta didik melalui pengintegrasian nilai-nilai pendidikan karakter. Penelitian ini bertujuan untuk mengetahui pengaruh dari misi, kurikulum, dan kepemimpinan perguruan tinggi terhadap perilaku antiradikalisme mahasiswa. Penelitian menggunakan pendekatan kuantitatif, dengan analisis regresi berganda, yaitu pada perguruan-perguruan tinggi yang mengamalkan faham ahlusunnah wal jama'ah, nasionalisme, dan berwawasan kebangsaan. Hasil penelitian menunjukkan bahwa faktor-faktor seperti kepemimpinan, kurikulum, dan misi perguruan tinggi berpengaruh positif dan signifikan terhadap perilaku anti-radikalisme mahasiswa.
\end{abstract}

Kata kunci: misi perguruan tinggi, kurikulum, kepemimpinan, perilaku radikalisme

\section{PENDAHULUAN}

Fenomena merebaknya paham radikal menjadi sorotan berbagai negara di dunia, termasuk Indonesia. Paham ini bukan hanya mendukung pandangan yang berbeda dengan yang didukung oleh orang kebanyakan, tetapi kerapkali mewujudkan perilaku ekstrim, teror, dan destruktif (Agung \& Santosa, 2018). Selain itu, dalam dinamika kehidupan berpolitik dan bernegara, informasi yang ada menunjukkan bahwa di beberapa bagian dunia terdapat fenomena munculnya dua kelompok yang saling berseberangan yang seringkali diistilahkan sebagai sayap kanan dan sayap kiri. Sayap kanan (right-wing) dicirikan dengan adanya atribut konservatisme, keberagamaan, dan liberalisme klasik. Sedangkan sayap kiri (leftwing) adalah hal-hal yang berkaitan dengan sosialisme, komunisme, dan marxisme. Hal tersebut seperti dikemukakan oleh Routray dan D'Souza (2013) bahwa left-wing extremism (LWE) di India, dipelopori oleh the Communist 
Party of India Maoist (CPI-Maoist). Sementara itu, Vampa (2009) mengatakan bahwa selama periode 1994-1996, dua arus sayap kiri terbentuk dari sisa-sisa Partai Komunis Italia yang lama yaitu yang reformis yang diwakili oleh Democratic Party of the Left dan yang radikal yang diwakili Communist Refoundation.

Peristiwa-peristiwa yang dilakukan baik oleh kelompok sayap kanan maupun kiri pernah terjadi di Indonesia. Pada masa awal kemerdekaan, pemerintah mengklaim DI/TII melakukan pemberontakan dan hendak mendirikan Negara Islam Indonesia; pada periode 1978 s.d.1980an muncul gerakan di Yogyakarta dan wilayah sekitarnya yang bertujuan membentuk Dewan Revolusi Islam Indonesia; pada tahun 1981 terjadi pembajakan pesawat Woyla yang merupakan gerakan menentang Pancasila dan UUD 1945; pada tahun 1965 terjadi pemberontakan yang dikenal dengan Gerakan September/PKI (Ma'arif, 2001). Gerakan kelompok-kelompok tersebut mengarah pada radikalisme dan menggunakan ancaman kekerasan dalam rangka mengintimidasi atau menyebar kepanikan sebagai alat untuk mempengaruhi keputusan politik. Persoalan yang rumit ini menjadi semakin merisaukan ketika para pelaku adalah kelompok anak bangsa yang produktif dan sedang bertumbuh-kembang menjadi sumber daya manusia potensial dalam pembangunan nasional.

Paham radikalisme perlu dicegah sejak dini di lingkungan keluarga, sekolah/perguruan tinggi, dan lingkungan masyarakat. Oleh karena itu, lembaga pendidikan mencoba membangun sikap anti-radikalisme para peserta didik melalui pengintegrasian nilai-nilai pendidikan antiterorisme atau anti-radikalisme meliputi citizenship, compassion, courtesy, fairness, moderation, respect for others, respect for the creator, self-control, dan tolerance ke dalam tujuan pembelajaran, materi pembelajaran, pengalaman belajar, dan evaluasi belajar (Wiyani, 2013).
Pencegahan paham radikalisme dan terorisme khususnya pada lingkungan perguruan tinggi sangat penting karena usia mahasiswa sangat rentan dengan pengaruh-pengaruh paham dari luar. Di sisi lain, mahasiswa memiliki kebebasan dan usia transisi antara masa remaja menuju usia dewasa. Hasil penelitian yang dilakukan oleh Kisbiyanto (2016) menunjukkan bahwa pada suatu sekolah tinggi di Kudus telah merumuskan isi kurikulum Pendidikan Agama Islam secara substansi tersebar di hampir semua mata kuliah dengan konten pada kecenderungan kurikulum dan pembejalaran yang antiradikalisme. Hal ini merupakan gerakan keislaman yang mengutamakan pendidikan dan dakwah secara damai, toleransi, mengutamakan kemanusiaan, dan menghormati perbedaan sebagai rahmat bagi semesta alam.

Pencegahan paham radikalisme di perguruan tinggi berkaitan dengan misi organisasi lembaga pendidikan yang bersangkutan. Misi organisasi adalah tujuan unik atau khusus yang menjadikan organisasi berbeda dengan organisasi sejenis lainnya dan menjelaskan lingkup operasi organisasi (Pearce II \& Robinson, 2007). Hasil studinya terhadap 72 lembaga pendidikan di Turkey, Ozdem (2011) menyimpulkan bahwa kesuksesan rencana strategis lembaga pendidikan bergantung pada formulasi yang benar dari pernyataan visi dan misi serta adanya partisipasi yang luas dalam proses perumusan. Makna dari hal ini adalah bahwa visi dan misi lembaga pendidikan sangat penting dalam mencapai tujuan pendidikan.

Kurikulum adalah keseluruhan program yang direncanakan, disusun, dilaksanakan, dan dievaluasi, serta dikembangkan oleh suatu program studi pada perguruan tinggi, dalam rangka menghasilkan lulusan yang memiliki capai pembelajaran tertentu yang direncanakan. Hasil-hasil penelitian Yasmin, Burhanuddin, Purwoko, (2008), Dina, Mawarsari, dan Suprapto, (2015), Nasrullah dan Susanto (2015), dan Sutjipto (2014) menunjukkan bahwa 
implementasi Kurikulum 2013 pada sekolah berpengaruh positif terhadap capaian peserta didik, baik kompetensi di bidangnya masingmasing, maupun sikap (sikap spiritual dan sikap sosial) dan perilakunya. Secara khusus implementasi Kurikulum 2013 menuntut guru melakukan inovasi pembelajaran dalam menanamkan pendidikan karakter yang terintegrasi, menghargai pendapat dan perbedaan, membangun kemandirian, serta upaya pembiasaan lainnya dalam menanamkan nilai dan kepribadian kepada peserta didik (Anwas, 2013).

Kepemimpinan (leadership) dalam konteks pendidikan, adalah kemampuan mengarahkan dan memberdayakan pendidik dan tenaga kependidikan yang didukung dengan sumber daya yang ada untuk menghasilkan peserta didik yang memiliki kompetensi dan perilaku sebagaimana diharapkan. Hasil-hasil penelitian Sun dan Leithwood (2015), Marks dan Printy (2003), Kadir dan Mohd. (2012) menunjukkan bahwa kepemimpinan pada lembaga pendidikan berpengaruh terhadap capaian kompetensi dan sikap serta perilaku para peserta didik.

Membangun pendidikan karakter di berbagai jenjang pendidikan termasuk perguruan tinggi sangat penting dalam mencegah paham radikalisme. Hasil penelitian Susanti (2013) menunjukkanbahwa pendidikan karakter di perguruan tinggi sangat diperlukan guna membentuk dan membangun mahasiswa agar menjadi pribadi yang berkarakter sesuai dengan nilai luhur ideologi negara Indonesia dan memperkokoh karakter yang didapat mahasiswa pada tingkat pendidikan sebelumnya. Pengintegrasian pendidikan karakter dalam perkuliahan dapat dilakukan dengan memasukkan nilai-nilai karakter dalam perencanaan (silabus dan Rencana Program Pembelajaran/ RPP), bahan ajar dan media, implementasi di kelas, penilaian, monitoring, dan evaluasi kegiatan secara keseluruhan (Winarni, 2013).
Penelitian yang dilakukan oleh Atok, Al Hakim, Untari, dan Margono (2015) terhadap dosen pengampu mata kuliah PKn dan mahasiswa pada tujuh perguruan tinggi, yaitu Universitas Negeri Malang, Institut Agama Islam Sunan Ampel Surabaya, Universitas Negeri Jember, Universitas Darul Ulum Jombang, Universitas Nusantara PGRI Kediri, Universitas Merdeka Pasuruan, dan IKIP PGRI Madiun menghasilkan simpulan bahwa ketersediaan daya dukung perguruan tinggi untuk mengembangkan model pembelajaran pendidikan karakter dengan pendekatan multikultural dalam mata kuliah PKn cukup tersedia dengan baik dilihat dari jumlah dan kualifikasi dosen, ketersediaan kurikulum, silabus, sarana teknologi informatika, maupun kultur mahasiswa. Penelitian-penelitian yang mengkaji secara bersama-sama tentang kontribusi misi organisasi, kurikulum, dan kepemimpinan lembaga pendidikan dalam membangun jiwa nasionalisme dan antiradikalisme para peserta didik masih sangat jarang dilakukan. Oleh karena itu, perlu dilakukan penelitian tentang pengaruh misi perguruan tinggi, kurikulum, dan kepemimpinan lembaga pendidikan terhadap perilaku anti-radikalisme mahasiswa.

Penelitian ini bertujuan untuk mengetahui 1) pengaruh misi perguruan tinggi terhadap perilaku anti-radikalisme mahasiswa; 2) pengaruh peran pemimpin perguruan tinggi terhadap perilaku anti-radikalisme mahasiswa; pengaruh kurikulum perguruan tinggi terhadap perilaku anti-radikalisme mahasiswa; 3) pengaruh misi perguruan tinggi, kurikulum, dan 4) peran pemimpin secara simultan berpengaruh positif terhadap perilaku anti-radikalisme mahasiswa.

Berdasarkan kajian teori dan hasil-hasil penelitian terdahulu maka dirumuskan hipotesis penelitian sebagai berikut: misi perguruan tinggi berpengaruh positif terhadap sikap antiradikalisme mahasiswa $\left(\mathrm{H}_{1)}\right.$; kurikulum berpengaruh positif terhadap sikap anti- 
radikalisme para mahasiswa $\left(\mathrm{H}_{2)}\right.$; kepemimpinan berpengaruh positif terhadap sikap antiradikalisme para mahasiswa $\left(\mathrm{H}_{3)}\right.$, dan secara simultan, misi perguruan tinggi, kurikulum, dan kepemimpinan bersama-sama berpengaruh positif terhadap sikap anti-radikalisme para mahasiswa $\left(\mathrm{H}_{4}\right)$.

\section{METODE}

Penelitian ini menggunakan pendekatan kuantitatif. Dalam penelitian ini ada tiga variabel independen, yaitu misi perguruan tinggi, kurikulum, dan kepemimpinan. Variabel dependen yaitu sikap anti radikalisme mahasiswa.

Penelitian ini dilakukan pada mahasiswa Institut $\mathrm{KH}$. Abdul Chalim Mojokerto, provinsi Jawa Timur. Populasi meliputi seluruh mahasiswa yang berjumlah 1.050 mahasiswa. Teknik pemilihan sampel yang digunakan adalah pengambilan sampel acak sederhana (a simple random sampling method) dan terpilih sebanyak 100 mahasiswa. Pemilihan teknik sampling ini didasarkan pada asumsi bahwa mahasiswa perguruan tinggi ini relatif homogen yaitu berasal dari warga nahdiyin dengan paham ideologi yang sama yaitu ahlus sunnah wal jama'ah. Pengumpulan data dilaksanakan selama bulan September 2017. Teknik pengumpulan data dari responden dilakukan melalui kuesioner dengan pertanyaan tertutup (closed questions). Mengingat semua variabel independen dan variabel dependen adalah tidak memiliki satuan hitung sehingga tidak bisa diukur (nonmeasurable variables), maka pengukuran terhadap semua variabel menggunakan skala Likert dengan rentang 1 sampai dengan 5 .

Kuesioner yang dikembangkan sebelum digunakan untuk pengumpulan data, dilakukan uji validitas dan reliabilitas. Hasil uji validitas instrumen menunjukkan bahwa semua indikator dari masing-masing variabel memiliki koefisien korelasi lebih besar dari 0,600 sehingga dapat disimpulkan bahwa instrumen penelitian adalah valid. Dengan kata lain, semua indikator merupakan alat yang benar untuk mengukur masing-masing variabel, baik variabel independen maupun variabel dependen. Selanjutnya, nilai Cronbach's Alpha setiap variabel adalah lebih besar dari 0,70, sehingga dapat disimpulkan bahwa instrumen penelitian reliabel. Artinya, semua indikator dari masing-masing variabel merupakan unsur yang bisa dipercaya untuk pengukuran variabel dalam penelitian. Oleh karena itu, kuesioner yang telah disusun dapat digunakan sebagai instrumen penelitian untuk pengungkapan dan pengumpulan data dari para responden.

Analisis data menggunakan regresi linier berganda (multiple linear regression analysis). Regresi linier berganda digunakan untuk mempelajari hubungan antara sebuah variabel dependen dengan satu atau lebih variabel independen (Greene, 2008). Bentuk fungsional dari hubungan antara variabel independen dengan variabel dependen adalah: $Y=a+\beta_{1} X_{1}$ $+\beta_{2} X_{2}+\beta_{3} X_{3}+$ error terms.

\section{HASIL DAN PEMBAHASAN}

Penelitian ini menggunakan tiga variabel independen $(X)$ yaitu misi perguruan tinggi, kurikulum, dan peran kepemimpinan perguruan tinggi. Misi perguruan tinggi diukur menggunakan indikator: berorientasi nasionalisme dan disosialisasikan dengan baik, dan dipahami dan dipraktekan dengan baik. Kurikulum Islam moderat diukur menggunakan indikator: berlandaskan ideologi paham, mata kuliah dan implementasi ahlus sunnah wal jama'ah. Variabel kepemimpinan diukur menggunakan indikator: memiliki sifat kharismatik, transformasional, dan visioner. Variabel dependen ( $Y$ ) adalah sikap anti-radikalisme yang diukur menggunakan indikator: mempelajari, memahami dan mempraktekkan ahlus sunnah wal jama'ah,

\section{Misi Perguruan Tinggi}

Hasil pengumpulan data berupa jawaban atas kuesioner melalui aplikasi SPSS (Statistical 
Package for Social Sciences) khususnya untuk keperluan analisis regresi linier berganda (multiple linear regression analyses). Adapun hasil pengolahan data tersebut sebagaimana dijelaskan pada Tabel 1.

Berdasarkan Tabel 1 dapat dilihat bahwa koefisien regresi variabel $\mathrm{X}_{1}\left(\beta_{1}\right)$ adalah tidak sama dengan 0 , yakni sebesar 0,148 dengan thitung $(2,711)$ yang lebih besar daripada t-tabel $(1,658)$ dan nilai signifikansi $(0,008)$ yang lebih kecil daripada $\alpha=0,05$. Dengan demikian menolak hipotesis null $\left(\mathrm{H}_{0}\right)$, dan sebaliknya menerima hipotesis alternatif ( $\mathrm{Ha})$. Artinya, hipotesis penelitian $\mathrm{H}_{1}$ telah terbukti, yakni bahwa secara statistik misi perguruan tinggi $\left(X_{1}\right)$ berpengaruh signifikan dan positif terhadap perilaku antiradikalisme para peserta didik $(Y)$. Ini artinya bahwa perilaku anti-radikalisme mahasiswa dipengaruhi oleh misi perguruan tinggi.

Hasil pendalaman melalui wawancara dan studi dokumentasi di lokasi penelitian diketahui bahwa Institut KH Abdul Chalim (IKHC), merupakan salah satu lembaga pendidikan di bawah naungan Yayasan Pendidikan Amanatul Ummah yang beraqidah Islam menurut faham Ahlusunnah Wal Jama'ah. Lembaga pendidikan ini memiliki komitmen kebangsaan yang kuat dalam bingkai empat pilar kebangsaan, yaitu Pancasila, Undang-Undang Dasar 1945, Negara Kesatuan Republik Indonesia, dan Bhineka Tunggal Ika yang merupakan karakter bangsa Indonesia. Hal ini tercermin dari visi lembaga yaitu terwujudnya manusia yang unggul, utuh dan berakhlaqul karimah untuk kemuliaan dan kejayaan Islam dan kaum Muslimin, kemuliaan dan kejayaan seluruh bangsa Indonesia dan untuk keberhasilan cita-cita kemerdekaan, yaitu terwujudnya kesejahteraan dan tegaknya keadilan bagi seluruh bangsa Indonesia. Dengan kata lain, IKHC memiliki cita-cita untuk mengembangkan ukhuwah Islamiyah dan ukhuwah wathoniyah, juga demi ukhuwah insaniyah sehingga akan menjadi relevan perannya tidak hanya dalam menyelesaikan persoalan nasional akan tetapi juga internasional dan bersifat universal.

Sebagai lembaga pendidikan yang berpaham ahlusunnah wal jama'ah, IKHC merupakan syuhud tsaqafi (penggerak kaum intelektual) dan sekaligus sebagai syuhud hadlori (penggerak peradaban). Di samping itu, seluruh civitas akademika IKHC memiliki sikap al-ikhlas (ketulusan), al-'adalah (keadilan), at-tawassuth (moderat), at-tawazun (keseimbangan), dan attasamuh (toleransi) sehingga mampu berkomunikasi, berinteraksi dan bersosialisasi dengan berbagai kalangan masyarakat Indonesia yang majemuk dengan berbagai suku, etnis, kelompok masyarakat, agama dan kepercayaan.

Melalui misi yang dimilikinya ini, IKHC berkomitmen untuk mewujudkan dimana proses pendidikan diarahkan untuk mencapai misi tersebut. Hal ini sejalan dengan pendapat Asropi (2013) bahwa misi organisasi yaitu 1) memberikan alasan keberadaan organisasi dan mengungkapkan siapa dan apa yang dilakukan organisasi; 2) memberikan informasi bagaimana visi akan diwujudkan; 3) menjelaskan kebutuhan dasar yang akan dipenuhi; 4) mengekspresikan nilai-nilai inti dari organisasi; dan 5) memuat kekhasan organisasi yang membedakan dari organisasi lain. Mengacu pada visi dan misi, maka

Tabel 1 Hasil Uji Regresi

\begin{tabular}{lccccccc}
\hline Model & \multicolumn{2}{c}{$\begin{array}{c}\text { Unstandardized } \\
\text { Coefficients }\end{array}$} & $\begin{array}{c}\text { Standardized } \\
\text { Coefficients }\end{array}$ & $\mathrm{t}$ & Sig. & $\mathrm{R}$ & $\mathrm{R}^{2}$ \\
\cline { 2 - 6 } & $\mathrm{B}$ & Std. Error & Beta & & & & \\
\hline (Constanst) & -.163 & .665 & & -.245 & .807 & 8,845 & 0,714 \\
Misi $\left(\mathrm{X}_{1}\right)$ & .148 & .054 & .174 & 2.711 & .008 & & \\
Kurikulum $\left(\mathrm{X}_{2}\right)$ & .149 & .054 & .178 & 2.735 & .007 & & \\
Kepemimpinan $\left(\mathrm{X}_{2}\right)$ & .746 & .066 & .676 & 11.353 & .000 & & \\
\hline
\end{tabular}


sebagai langkah selanjutnya adalah menentukan tujuan organisasi (Holpp, 2012) dalam rangka a) menetapkan kinerja organisasi yang diharapkan; b) memastikan bahwa para anggota organisasi telah bekerja pada pekerjaan yang benar dan dengan cara yang benar; c) fokus pada pengukuran dan hasil, bukan sekedar aktivitas; d) menghubungkan aktivitas seharihari dengan tujuan organisasi secara luas; e) standar capaian kinerja organisasi; f) mengembangkan komunikasi antarpegawai dalam menghadapi tantangan dan sasaran pekerjaan; dan g) membangun inisiatif melakukan diskusi tentang pengembangan karir setiap personal.

Misi organisasi lembaga pendidikan mengarahkan pada proses dan hasil organisasi. Pernyataan misi organisasi berkaitan dengan a) produk dan jasa-layanan yang dihasilkan; b) pemangku kepentingan (stakeholders); c) proses bisnis; d) budaya organisasi dan kualitas; dan e) nilai tambah. Dengan kata lain, bahwa pernyataan misi akan menentukan apa tujuan organisasi yaitu berupa hasil yang akan dicapai. Dengan demikian, dalam bidang pendidikan, tujuan organisasi perguruan tinggi adalah menghasilkan lulusan yang memiliki kompetensi akademis dan perilaku atau karakter sebagaimana diharapkan.

Misi sebagai penjabaran lebih lanjut dari visi perguruan tinggi mempunyai peran utama dalam menentukan tujuan dan capaian organisasi. Ketika IKHC mempunyi visi dan misi yang dilandasi oleh faham ahlusunnah wal jama'ah, nasionalisme dan berwawasan kebangsaan yang dibingkai dalam empat pilar kebangsaan, yaitu Pancasila, UUD1945, NKRI dan Bhineka Tunggal Ika, maka jelas kiranya seluruh civitas akademika IKHC bertekad untuk menolak radikalisme yang ingin merobohkan empat pilar kebangsaan tersebut. Oleh karena itu, untuk menangkal paham radikalisme pada lembaga pendidikan, perlu tersurat dalam misi lembaga pendidikan tersebut.

\section{Kurikulum Perguruan Tinggi}

Variabel selanjutnya yaitu kurikulum. Dari Tabel 1 diperoleh koefisien regresi variabel $X_{2}\left(\beta_{2}\right)$ adalah tidak sama dengan 0 , yakni sebesar 0,149 dengan t-hitung $(2,735)$ yang lebih besar daripada t-tabel $(1,658)$ dan nilai signifikansi $(0,007)$ yang lebih kecil daripada $\alpha=0,05$. Ini artinya menolak hipotesis null $\left(\mathrm{H}_{0}\right)$, sebaliknya menerima hipotesis alternatif ( $\mathrm{Ha})$. Hal ini menunjukkan hipotesis penelitian $\mathrm{H}_{2}$ telah terbukti yaitu bahwa secara statistik, kurikulum $\left(\mathrm{X}_{2}\right)$ mempunyai pengaruh positif secara signifikan terhadap sikap anti-radikalisme para peserta didik $(Y)$. Dengan kata lain, sikap anti radikalisme mahasiswa dipengaruhi oleh kurikulum lembaga pendidikan tersebut.

Kurikulum pendidikan tinggi merupakan program untuk menghasilkan lulusan, sehingga program tersebut seharusnya menjamin agar lulusannya memiliki kualifikasi yang setara dengan kualifikasi yang disepakati dalam KKNI (Kementerian Riset, Teknologi, dan Pendidikan Tinggi, 2016). Berdasarkan Undang-Undang Nomor 12 Tahun 2012 tentang Pendidikan Tinggi Pasal 35 Ayat (1) dinyatakan bahwa penyusunan kurikulum adalah hak perguruan tinggi, tetapi selanjutnya dinyatakan harus mengacu kepada standar nasional. Kurikulum pendidikan tinggi dikembangkan oleh setiap Perguruan Tinggi dengan mengacu pada Standar Nasional Pendidikan Tinggi untuk setiap Program Studi yang mencakup pengembangan kecerdasan intelektual, akhlak mulia, dan keterampilan. Sesuai dengan peraturan tersebut, kurikulum IKHC dikembangkan oleh lembaga ini, namun pengembangan tersebut mengacu pada standar nasional pendidikan tinggi tersebut.

Kurikulum dan segala perangkatnya, seperti Rencana Pembelajaran Semester (RPS)/silabus, model pembelajaran, prasarana dan sarana pembelajaran sebagai perwujudan operasional dalam penyelenggaraan pendidikan merupakan cerminan daripada visi dan misi IKHC. Dengan demikian, kurikulum IKHC berlandaskan pada 
paham ahlusunnah wal jama'ah, antara lain mengandung nilai-nilai al-ikhlas (ketulusan), al'adalah (keadilan), at-tawassuth (moderat), attawazun (keseimbangan), dan at-tasamuh (toleransi) dan berwawasan kebangsaan yang kokoh dengan dibingkai dalam empat pilar kebangsaan.

Hasil pendalaman di lokasi penelitian menunjukkan bahwa berbeda dengan perguruan tinggi Islam lainnya, IKHC mewajibkan bagi seluruh mahasiswa untuk menempuh mata kuliah ahlusunnah wal jama'ah agar mereka mempelajari, memahami dan mengimplementasikan dalam kehidupan sehari-hari. Setiap mahasiswa dibiasakan untuk mengamalkan ajaran tersebut dalam membentuk pribadi yang berkarakter. Materi kurikulum perlu dibangun untuk meningkatkan nilai-nilai perilaku peserta didik ke arah yang lebih baik (Warsihna \& Anwas, 2017). Menurut Nuryanto (2016), pembentukan karakter bukan hanya dipengaruhi oleh faktor genetik tetapi ada pembiasaan dan keteladanan yang diajarkan terus menerus baik di lingkungan keluarga, lingkungan sekolah, dan lingkungan eksternal. Kaimuddin (2014) menambahkan bahwa pendidikan karakter merupakan usaha sadar yang terencana dan terarah melalui lingkungan pembelajaran untuk tumbuh kembangnya seluruh potensi manusia yang memiliki watak dan kepribadian baik, bermoralberakhlak, dan berefek positif konstruktif pada alam dan masyarakat.

Terkait pendidikan karakter mahasiswa, Tanis (2013) berpendapat bahwa pendidikan karakter bertujuan untuk menciptakan mahasiswa agar memiliki kerendahan hati, memiliki keberanian (courage) dalam arti mereka benarbenar punya keberanian menegakkan sesuatu yang dianggap benar dan bertanggung jawab, serta tidak memiliki keraguan. Penanaman pendidikan karakter dalam lembaga pendidikan formal diperlukan adanya proses, pembiasaan, dan contoh teladan dari guru/dosen, orangtua, dan sesama teman sebayanya (Anwas, 2010)).
Kurikulum IKHC menanamkan pendidikan karakter melalui proses pembiasaan dalam mengamalkan ahlusunnah wal jama'ah dalam keseharian mahasiswa, dosen, tenaga administrasi, serta semua personil lembaga pendidikan tersebut.

\section{Kepemimpinan}

Variabel peran pemimpin perguruan tinggi, berdasarkan Tabel 1 diperoleh koefisien regresi variabel $X_{3}\left(\beta_{3}\right)$ adalah tidak sama dengan 0 , yakni sebesar 0,746 dengan t-hitung $(11,353)$ yang lebih besar daripada t-tabel $(1,658)$ dan nilai signifikansi $(0,000)$ yang lebih kecil daripada $\alpha=0,05$. Hasil ini membuktikan bahwa menolak hipoteis null $\left(\mathrm{H}_{0}\right)$, dan menerima hipotesis alternatif ( $\mathrm{Ha}$ ). Artinya, secara statistik variabel kepemimpinan $\left(\mathrm{X}_{3}\right)$ berpengaruh positif dan signifikan terhadap perilaku anti-radikalisme para peserta didik (Y). Dengan kata lain, perilaku anti-radikalisme mahasiswa IKHC dipengaruhi secara signifikan oleh kepemimpinan lembaga pendidikan tersebut. Hal ini sejalan dengan hasil penelitian Sun dan Leithwood (2015) yang menunjukkan bahwa kepemimpinan Lembaga Pendidikan termasuk perguruan tinggi, mempengaruhi capaian peserta didik yang pada umumnya tidak secara langsung, yakni melalui mediasi kompetensi dan perilaku para pendidik. Marks dan Printy (2003) berpendapat bahwa integrasi antara kepemimpinan transformasional dan kepemimpinan instruksional meningkatkan kemampuan pedagogi pendidik dan pada akhirnya berdampak pada kenaikan tingkat capaian kompetensi dan perilaku peserta didik.

Kepemimpinan merupakan kemampuan untuk mempengaruhi sebuah kelompok orang menuju pencapaian tujuan (Robbins, 2001). Seluruh jajaran pimpinan pada IKHC yang turut terlibat dalam perumusan visi dan misi perguruan tinggi mempunyai tanggung jawab untuk mensosialisasikan, memahamkan, menginternalisasi, dan memberikan teladan kepada semua civitas akademika, antara lain termasuk para peserta didik tentang makna dan maksud visi dan misi 
tersebut. Berdasarkan neocharismatic theories, kepemimpinan dibedakan menjadi tiga yaitu: kepimpinan kharismatik (charismatic leadership), kepemimpinan transformasional (transformational leadership), dan kepemimpinan visioner (visionary leadership). Agar hal ini berjalan dengan baik, para pemimpin pada IKHC dituntut mempunyai sifat kepemimpinan yang karismatik, transformasional dan visioner, sehingga visi, misi dan tujuan perguruan tinggi dapat dicapai sebagaimana diharapkan oleh semua stake-holders, yang di dalamnya termasuk para peserta didik. Adanya pengaruh faktor peran pemimpin perguruan tinggi terhadap perilaku antiradikalisme mahasiswa (Tabel 1 ) menunjukkan bahwa para pemimpin pada lembaga tersebut mampu mengarahkan dan memberdayakan tenaga pendidik dan kependidikan didukung dengan sumber daya yang ada untuk menghasilkan lulusan yang sesuai visi dan misi lembaga pendidikan.

\section{Kontribusi Simultan}

Tabel 1 menunjukkan bahwa koefisien regresi (R) sebesar 0,845 dengan nilai F-hitung $(79,882)$ yang lebih besar daripada F-tabel $(5,66)$, sehingga dapat disimpulkan bahwa misi perguruan tinggi $\left(X_{1}\right)$, kurikulum $\left(X_{2}\right)$, dan kepemimpinan $\left(X_{3}\right)$ mempunyai pengaruh yang cukup kuat dengan sikap anti-radikalisme para peserta didik (Y). Di samping itu, diperoleh koefisien determinasi (the coefficient of determination), $\mathrm{R}^{2}$, sebesar 0,714 dengan nilai F-hitung $(79,882)$ lebih besar dari nilai F-tabel $(5,66)$ sehingga dapat diputuskan bahwa menolak hipotesis null $\left(\mathrm{H}_{0}\right)$, dengan kata lain menerima hipotesis alternatif $(\mathrm{Ha})$ yang berarti hipotesis penelitian $\mathrm{H}_{4}$ telah terbukti. Artinya, misi perguruan tinggi, kurikulum, dan kepemimpinan secara simultan berpengaruh positif dan signifikan terhadap sikap anti-radikalisme para peserta didik, dengan kontribusi sebesar $71,40 \%$. Artinya, sebesar $71,40 \%$ perilaku antiradikalisme para mahasiswa dipengaruhi oleh misi perguruan tinggi, kurikulum, dan kepemimpinan.

Adapun sisanya sebesar $28,60 \%$ ditentukan oleh variabel lain (di luar ketiga variabel tersebut) yang tidak dimasukkan dalam model penelitian ini. Faktor-faktor tersebut misalkan: kondisi lingkungan di luar kampus (di rumah, kelompok pergaulan, masyarakat, dan informasi media sosial), pengembangan karakter pada jenjang pendidikan sebelumnya seperti sekolah dasar, sekolah lanjutan tingkat pertama (SMP atau MTs) dan sekolah lanjutan tingkat atas (SMA, MA, atau SMK), dan sikap serta ideologi orang tua. Rumbaru dan Hasse (2016) berpendapat bahwa untuk mereduksi berbagai pemahaman yang mengarah pada radikalisme, dibutuhkan pendekatan atau tafsir yang komprehensif untuk memahami doktrin agama. Salah satu model atau metode yang dapat dilakukan adalah melalui hermeneutik. Dengan tafsir ini, pemahaman terhadap teks agama (ayat) dilakukan secara luas, yang tidak hanya terpaku pada teks yang dikaji, tetapi juga memperhatikan dan menyimak secara mendalam konteks sosial dari teks tersebut. Langkah lain untuk membendung atau mengeliminir gerakan anti-radikalisme dalam pendidikan adalah dengan cara memperkuat pola jaringan kerjasama internal sekolah dan jaringan eksternal antar sekolah dengan masyarakat, termasuk orang tua (Muchith, 2016).

Berdasarkan hasil pengelohan data yang tersaji pada tabel 1, diperoleh kenyataan bahwa dibandingkan variabel misi perguruan tinggi $\left(X_{1}\right)$ dan variabel kurikulum $\left(\mathrm{X}_{2}\right)$, ternyata variabel kepemimpinan $\left(X_{3}\right)$ mempunyai koefisien regresi $\left(\beta_{3}\right)$ terbesar yakni 0,746 dibandingkan dengan $\beta_{1}(0,148)$ dan $\beta_{2}(0,149)$. Artinya, bahwa variabel kepemimpinan $\left(X_{3}\right)$ mempunyai pengaruh atau kontribusi terbesar terhadap perubahan sikap anti-radikalisme para peserta $\operatorname{didik}(Y)$. Hal ini dapat dimengerti karena pemimpin mempunyai kewajiban merumuskan dan menetapkan misi lembaga, sekaligus memberikan pengarahan pengimplementasian 
misi lembaga melalui penetapan tujuan dan sasaran lembaga serta strategi pencapaian sasaran dengan cara menentukan kurikulum yang kemudian diterjemahkan kedalam strategi pembelajaran, termasuk monitoring dan evaluasi kinerja lembaga. Dengan demikian, pemimpin dengan berbagai model kepemimpinan memegang peran sentral terhadap bagaimana capaian para peserta didik. Hasil penelitian tersebut berimplikasi bahwa proses pendidikan pada lembaga pendidikan khususnya perguruan tinggi diharapkan bahwa mahasiswa tidak hanya memiliki kompetensi akademis, tetapi juga berperilaku baik, antara lain: beribadah dengan tekun, beradab, beretika, toleran, menghargai dan menghormati pihak lain, berjiwa nasionalis, serta bersikap anti-radikalisme.

Dalam menanggulangi radikalisme yang bercirikan terorisme, pemerintah seyogyanya tidak hanya menggantungkan kepada lembaga khusus, Badan Nasional Penanggulangan Terorismen (BNPT) tetapi harus dilakukan bersama-sama dengan seluruh lembaga pendidikan, dari jenjang terendah sampai pendidikan tinggi, serta bersama-sama bersinergi dengan berbagai kelompok masyarakat. Hal ini terbukti dalam penelitian ini bahwa penyelenggaraan pendidikan, mulai dari misi perguruan tinggi, kurikulum dan kepemimpinan mempunyai pengaruh positif signifikan terhadap sikap antiradikalisme para peserta didik. Perlu pula kiranya dicatat tentang adagium "lebih baik mencegah daripada mengobati" sehingga sebagai bentuk realisasi dari pernyataan ini adalah menyelenggarakan pendidikan karakter anak bangsa adalah lebih baik daripada melakukan pemberantasan dan penumpasan anak-bangsa sendiri yang tengah tersesat dalam faham radikalisme.

Penelitian ini mempunyai keterbatasan dalam obyek atau jangkauan penelitian yang hanya difokuskan pada para mahasiswa yang berasal dari satu lembaga pendidikan tinggi saja, yaitu Institut KH Abdul Chalim. Di samping itu, penelitian ini dilakukan dengan pendekatan kuantitatif dalam bentuk statistik inferensial yang masih belum menunjukkan informasi yang komprehensif sehingga simpulannya terbatas pada perspektif statistik semata. Oleh karena itu, diperlukan penelitian lanjutan dengan pendekatan yang berbeda serta populasi dan sampel yang lebih komprehensip.

\section{SIMPULAN DAN SARAN}

Faktor kepemimpinan perguruan tinggi, kurikulum, dan misi perguruan tinggi berpengaruh positif dan signifikan terhadap perilaku antiradikalisme mahasiswa pada perguruan tinggi yang menanamkan perilaku pembiasaaan dalam kehidupan sehari-hari seperti mengamalkan paham ahlusunnah wal jama'ah, nasionalisme, dan berwawasan kebangsaan. Variabel yang paling berpengaruh dimulai dari kepemimpinan perguruan tinggi, kurikulum, dan misi perguruan tinggi yang secara simultan berpengaruh positif dan memiliki kontribusi yang besar terhadap pembentukan perilaku anti-radikalisme mahasiswa.

Untuk menangkal paham dan perilaku radikalisme khususnya pada mahasiswa, hendaknya setiap perguruan tinggi memiliki misi yang diwujudkan dalam kurikulum serta implementasinya melalui pembiasaan perilaku keseharian. Selain itu, peran pimpinan lembaga pendidikan sangat penting dalam membuat kebijakan atau aturan untuk menangkal perilaku radikalisme mahasiswa melalui komitmen, yang diwujudkan dalam bentuk visi, misi, kurikulum, serta contoh keteladanan dari para pemimpin tersebut. Perlu juga dilakukan penelitian lebih lanjut dengan pendekatan yang berbeda serta populasi dan sampel yang lebih luas dan komprehensif.

Pemerintah perlu membuat regulasi atau menguatkan kebijakan yang telah ada yang mengharuskan setiap jenjang pendidikan untuk mengimplementasikan kurikulum bermuatan pembentukan dan pengembangan karakter peserta didik, termasuk wawasan kebangsaan 
(Pancasila, UUD 1945, NKRI dan Bhinneka Tunggal Ika) dan sikap sebagaimana terkandung dalam paham ahlusunnah wal jama'ah, antara lain: toleran, keseimbangan, moderat, adil, dan tulus, ikhlas, serta cita-cita untuk mengembangkan ukhuwah Islamiyah dan ukhuwah wathoniyah, juga demi ukhuwah insaniyah

\section{PUSTAKA ACUAN}

Agung, I. \& Santosa, A. (2018). Pola deteksi dini dalam menangkal faham radikalisme di lingkungan pendidikan. Jakarta: Penerbit Edu Pustaka.

Anwas, O.M. (2010). Televisi mendidik karakter bangsa: Peluang dan tantangan. Jurnal Pendidikan dan Kebudayaan, 16 (9), 256-266.

Anwas, O.M. (2013). Peran teknologi informasi dan komunikasi dalam implementasi kurikulum 2013. Jurnal Teknodik, 17(1), 493-504.

Asropi. (2013). Perencanaan: definisi dan konsep. Ciamis: Badan Perencanaan Pembangunan Daerah, Pemerintah Kabupaten Ciamis.

Atok, A.R, Al Hakim, S., Untari, S., \& Margono. (2015). Model pembelajaran pendidikan karakter dengan pendekatan multikultural dalam pendidikan kewarganegaraaan di perguruan tinggi. Jurnal Pendidikan Pancasila dan Kewarganegaraaan, 28(1), 20-30.

Dina, A., Mawarsari, V.D., \& Suprapto, R. (2015). Implementasi kurikulum 2013 pada perangkat pembelajaran model discovery learning pendekatan scientific terhadap kemampuan komunikasi matematis materi geometri SMK. Jurnal Karya Pendidikan Matematika 2 (1), 22-31.

Greene, W.H. (2008). Econometric analysis. $6^{\text {th }}$ edition. New Jersey: Pearson-Prentice Hall. Holpp, L. (2012). Win-win performance appraisal. New York: McGraw-Hill.

Kadir, N.A.A. \& Mohd. R.M.N. (2012). The role of ulama in reconstructing of religious education in malaysia during early $20^{\text {th }}$ century. Middle-East Journal of Scientific Research, 11(9), 1257-1265.

Kaimuddin. (2014). Implementasi pendidikan karakter dalam kurikulum 2013. Dinamika IImu. 14(1), 47-63.

Kementerian Riset, Teknologi, dan Pendidikan Tinggi. (2016). Buku panduan penyusunan kurikulum pendidikan tinggi. Direktorat Pembelajaran, Direktorat Jenderal Pembelajaran dan Kemahasiswaan.

Kisbiyanto. (2016). Manajemen kurikulum dalam perspektif anti-radikalisme. ADDIN, 10(1), 181206.

Ma'arif, B.S. (2001) Dari ekstrim kanan ke terorisme. MIMBAR, 26(2), 169-181

Marks, H.M \& Printy, S.M. (2003). Principal leadership and school performance: An integration of transformational and instructional leadership. Educational Administration Quarterly, 39(3), 370-397.

Muchith, M.S. (2016). Radikalisme dalam dunia pendidikan. ADDIN, 10(1), 163-180.

Nasrullah, H. \& Susanto, A. (2015). Efektivitas penerapan kurikulum 2013 terhadap motivasi belajar siswa kelas x program keahlian teknik kendaraan ringan SMK ma'arif 1 kebumen. Jurnal Pendidikan Teknik Otomotif Universitas Muhammadiyah Purworejo, 5(1). 
Nuryanto. (2016). Integrasi nilai pendidikan karakter dalam pengembangan kurikulum berbasis kkni untuk perguruan tinggi. Edukasi. 4,(2), 234-252.

Ozdem, G. (2011). An analysis of the mission and vision statements on the strategic plans of higher education institutions. Educational Science: Theory \& Practice. 11(4), 1887-1894.

Pearce II, J. A.\& Robinson, R.B. (2007). Strategic management. New York: McGraw-Hill Irwin.

Robbins, S.P. (2001). Organizational Behavior. Upper Saddle River: Prentice Hall.

Routray, B.P. \& D'Souza, S. M. (2013). Countering left-wing extremism in india: conceptual ambiguity and operational disconnect. ISAS Insights, No. 213.

Rumbaru, M \& Hasse, J. (2016). Radikalisme agama legitimasitafsir kekerasan di ruang publik. AlUlum, 16(2).

Sun, J. \& Leithwood, K. (2015). Leadership effects on student learning mediated by teacher emotions. Societies, 5, 566-582.

Susanti, R. (2013). Penerapan pendidikan karakter di kalangan mahasiswa. Jurnal Al-Ta'lim. 1(6), 480-487.

Sutjipto. (2014). Dampak pengimplementasian kurikulum 2013 terhadap performa siswa sekolah menengah pertama. Jurnal Pendidikan dan Kebudayaan, 20(2), 187-199.

Tanis, H. (2013). Pentingnya pendidikan character building dalam pembentukan kepribadian mahasiswa. Humaniora, 4(2),1212-1219.

Undang-undang Dasar 1945. http://www.hukumonline.com/pusatdata/download/ It4ca2ed7ef3cb1/node/lt4ca2eb6dd2834, diakses 12 Januari 2018.

Undang-Undang Nomor 12 Tahun 2012 tentang Pendidikan Tinggi. http:// sumberdaya.ristekdikti.go.id/wp-content/uploads/2016/02/uu-nomor-12-tahun-2012-ttgpendidikan-tinggi.pdf, diakses 12 Januari 2018.

Vampa, D. (2009). The death of social democracy: The case of the italian democratic Party. Bulletin of Italian Politics. 1(2), 347-370.

Warsihna, J \& Anwas, O. M. (2017). Curriculum model for improving quality of life for remote indigonous community (research on Baduy tribel of Banten province, Indonesia). Turkish Online Journal of Educational Technologi - TOJET, Special Issue for INTE 2017, 680-687.

Winarni, S. (2013). Integrasi pendidikan karakter dalam perkuliahan. Jurnal Pendidikan Karakter. 3(1), 95-107.

Wiyani, N.A. (2013). Pendidikan agama Islam berbasis anti terorisme di SMA. Jurnal Pendidikan Islam. 2, (1), 65-83.

Yasmin, L. S, Burhanuddin, Purwoko, A.A. (2008). Perubahan kurikulum dan kinerja guru MIPA di SMA negeri se-kota Mataram. Forum Kependidikan, 28(1), 37-42. 